\title{
The 'Brown Rot' Diseases of Fruit Trees, with Special Reference to two Biologic Forms of Monilia cinerea, Bon. ${ }^{1}$ II.
}

\author{
BY \\ H. WORMALD, M.Sc. (Lond.), A.R.C.Sc. \\ Mycological Department, South-Eastern Agricultural College, Wye, Kent.

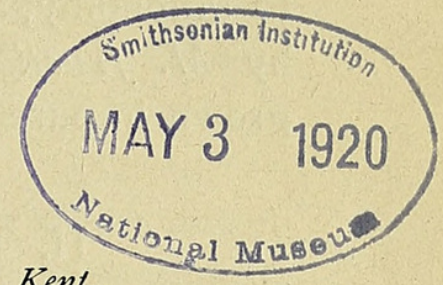

With Plates IV and V.

CONTENTs.

II. The Secretion of an Oxidizing Enzyme by Monilia cinerea . . . . 144

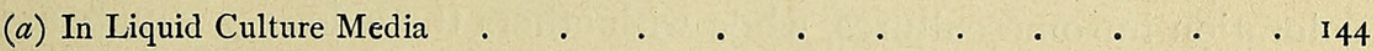

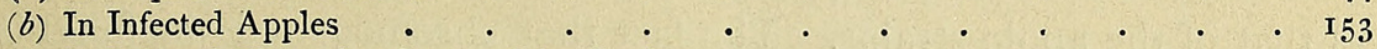

(c) In Infected Flowering Spurs of the Apple . . . . . . . . I54

III. Morphology and Taxonomy of the 'Brown Rot' Fungi • . • $\quad$ I59

(a) Colour and Size of Pustules. . . . . . . . . . . . . I59

(b) Dimensions of Conidia . . . . . . . . . . . . 160

(c) Viability of Conidia . . . . . . . . . . . . . . 163

(a) Cultural Studies . . . . . . . . . . . . . . . . . $^{16} 4$

(e) American Strains of Monilia . . . . . . . . . . 165

$(f)$ Taxonomy . . . . . . . . . . . . . . . . 166

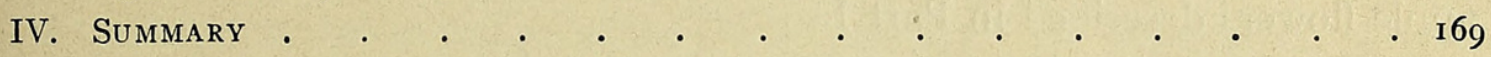

\section{INTRODUCTION.}

T N Part I of this article it was shown that the 'Brown Rot' diseases of fruit trees in this country are caused not only by Monilia fructigena, which has been generally assumed to be the species responsible for all such diseases in Britain, but also by $M$. cinerea, the latter having been found, in many cases, to be more destructive than $M$. fructigena; the two species are to be recognized by their morphological characters and by their mode of parasitism. Further, it was pointed out that the morphological species $M$. cinerea includes two 'biologic' forms distinguished by the degree of virulence when apple flowers are inoculated with their conidia; one form, found on infected flowering shoots and cankers of apple trees, is able to

1 This article is included in a Thesis approved for the Degree of Doctor of Science in the University of London.

[Annals of Botany, Vo1. XXXIV. No. CXXXIV. April, 1920.] 
produce a blossom wilt and cause cankers on the branches by infection through the flowers; the other kills only the flower actually inoculated, infection extending no farther than the pedicel of the infected apple flower.

In the following pages experiments are described which show that the two biologic forms of Monilia cinerea can be distinguished in the laboratory by biochemical methods. The value of the application of cultural methods to taxonomy, as illustrated by certain distinguishing characters exhibited by $M$. fructigena, $M$. cinerea, and an American form of Monilia when grown in pure cultures, is also discussed.

\section{The Secretion of an Oxidizing Enzyme by MONILIA CINEREA.}

When growing on agar, prepared with an extract of prunes as its nutrient constituent, at room temperature (about $\mathrm{I} 8^{\circ} \mathrm{C}$.), the apple Blossom Wilt strains of Monilia cinerea invariably give rise to a dark brown coloration. Strains from other sources developed this browning in varying degrees; a few remained quite hyaline on that medium or produced merely a slight coloration in some cultures, while with others the colour was quite as intense as that of the apple strains. The fact that chromogenesis in fungi is often due to the action of oxidizing agents elaborated by the organisms suggested the presence of an enzyme (probably an oxidase) in the Monilia cultures, and experiments were initiated with the object of ascertaining whether such an enzyme could be detected and identified. The results, though they showed no close correlation with the coloration of the agar cultures, proved to be of particular interest in relation to the inoculation experiments on apple flowers described in Part I.

\section{(a) The Enzyme in Liquid Culture Media.}

Preliminary experiments were carried out with two strains used in the inoculations of apple flowers made in 1917, viz. an apple Blossom Wilt strain, and one obtained from a vegetative shoot of a plum tree affected with the 'Wither Tip' disease. The former, in common with all other strains obtained from apple spurs and cankers, developed a dark brown coloration on prune extract agar, while the latter in a few cultures produced a little browning, but generally remained quite hyaline. The Wither Tip strain had failed to produce a blossom wilt when apple flowers were inoculated with it.

In the first experiment of this series the two strains, here referred to for convenience as A (apple strain) and B (plum strain) respectively, were grown at room temperature in Petri dishes containing a sterilized extract of apples. After 16 days the liquids were poured from the dishes into wide test-tubes, when it was seen that in both cases they were darker than the 
original culture medium and that the liquid from A was distinctly darker than that from B.

Four c.c. of emulsified gum guaiacum were poured into each of two test-tubes; to one tube was added I c.c. from culture $A$ and to the other I c.c. from B. At the end of 30 minutes the contents of the first tube were a bright blue, while the latter was unchanged, though a very faint bluish tint could be detected after 4 hours. Two other tubes similarly prepared shortly afterwards gave a similar result. When either liquid was heated in a waterbath at $100^{\circ} \mathrm{C}$. for $2 \frac{1}{2}$ minutes, before adding the emulsion, no trace of the blue coloration appeared.

The mycelium from these cultures was washed with distilled water, dried in a thermostat at $30^{\circ} \mathrm{C}$., cut up into small pieces, and stored in stoppered bottles until required. $0 \cdot 1 \mathrm{grm}$. of the dried mycelium of each strain was weighed out, soaked in a few c.c. of water, and pounded in a mortar to obtain an extract which was finally made up to 50 c.c. These extracts were tested for oxidase in the same manner as employed for the culture media. In this case the plum strain gave the reaction for oxidase, but not the apple strain.

The results go in the direction of showing that both strains produce the oxidase, but that the apple strain secretes it more readily into the culture medium.

In another experiment, using the same two strains, similar plate cultures were prepared, eight in number, viz. :

$$
\begin{aligned}
& \mathrm{A}_{1}, \mathrm{~A}_{2}, \mathrm{~A}_{3}, \mathrm{~A}_{4} \text {, inoculated with the apple strain ; } \\
& \mathrm{B}_{1}, \mathrm{~B}_{2}, \mathrm{~B}_{3}, \mathrm{~B}_{4}, \quad " \quad \text { plum },
\end{aligned}
$$

Of these Nos. I and 2 of each set were incubated at $25^{\circ}$ C., while Nos. 3 and 4 were kept at room temperature (about $18^{\circ} \mathrm{C}$.). At the end of 9 days Nos. 2 and 4 of both sets were tested for the presence of oxidase in the liquid, with the following colour changes in the test-tubes at the end of I hour :
A 2, deep blue;
A 4, dark blue;
$\mathrm{B} 2$, very faint bluish tint;
B 4, no colour change.

Seven days later the remaining four plates were similarly tested:
A I, deep blue;
$\mathrm{A}_{3}$, deep blue;
$\mathrm{B}$ I, very faint bluish tint ;
$\mathrm{B}_{3}$, no colour change.

It will be seen that the apple strain gave approximately identical results at the end of 9 and of 16 days and whether incubated or kept at room temperature; the liquid in which the plum strain had been growing, however, 


\section{I46 Wormald.- 'Brown Rot' Diseases of Fruit Trees. II.}

gave no oxidase reaction in the culture grown at the lower temperature and only a very faint reaction in the one at the higher.

In this and subsequent experiments it was generally found that the colour reaction in the test-tubes reached its greatest intensity in 2 to 3 hours, after which the colour gradually faded, but often a trace remained after 24 hours.

Cultures were also grown in flasks containing 200 c.c. of the apple extract, kept at room temperature, so that portions of the culture medium could be removed at intervals of a few days and subjected to the oxidase test.

The strains used in this experiment were :

A. The apple Blossom Wilt strain used in the preceding experiment.

B. The plum Wither Tip strain used in the preceding experiment.

D. $\}$ Two other Wither Tip strains.

E. Strain of Monilia obtained from America.

By means of a sterile pipette Io c.c. of the culture medium were removed from each flask at intervals of $9,15,37$, and 58 days from the time the cultures were started, and the guaiacum test applied. The maximum colour change given by the five strains was as follows:

\section{Reaction to Guaiacum Test.}

\begin{tabular}{|c|c|c|c|c|c|}
\hline $\begin{array}{l}\text { of culture. } \\
9 \text { days } \\
\text { I } 5 \text { days } \\
37 \text { days }\end{array}$ & $\begin{array}{c}A . \\
\text { pale blue }\end{array}$ & $\begin{array}{l}\quad B . \\
\text { no change } \\
\text { very pale blue }\end{array}$ & $\begin{array}{c}C . \\
\text { no change } \\
, y\end{array}$ & $\begin{array}{c}D . \\
\text { no change } \\
\text {, }\end{array}$ & $\begin{array}{c}E \text {. } \\
\text { deep blue } \\
\text { very deep blue }\end{array}$ \\
\hline
\end{tabular}

The results show that although the plum strains are capable of secreting the oxidase into the culture medium, the enzyme is set free far more readily by the apple strain and the American form of Monilia during the period of vigorous growth.

The colour of the culture medium (apple extract) in which the fungi had been growing for some time was generally darker than before inoculation, and the depth of colour was correlated with the intensity of the oxidase reaction given by the liquid. Thus the liquid of the cultures of the apple strains and of the American form of Monilia was invariably darker than those of the plum strains, and proved to give a more intense reaction to the oxidase test.

Experiments carried out with the object of identifying the oxidase showed that it had no action on tyrosin or hydroquinone; it could not therefore be referred either to tyrosinase or laccase, two oxidases which have been found in fungi. On the other hand it rapidly produces a brownish yellow colour in solutions of tannic acid, gallic acid, and pyrogallic acid. In this respect it behaves as the enzyme oenoxydase found by Martinand $(16,17)$ in ripe grapes and ascertained by Laborde (14) to be secreted by 


\section{Wormald.- 'Brown Rot' Diseases of Fruit Trees. II. I47}

Botrytis cinerea when growing on grapes and on sterilized wine 'must'. This enzyme, however, is described as oxydizing hydroquinone, while in repeated experiments with the oxidizing enzyme of Monilia cinerea no action on hydroquinone could be detected.

Martinand found that oenoxydase is destroyed by heating to $72^{\circ} \mathrm{C}$. and keeping it at that temperature for four minutes. The Monilia enzyme also loses its power of oxidation when similarly heated. In most of the experiments described below the control tubes were heated for two minutes in a water-bath at $100^{\circ} \mathrm{C}$. In one experiment, however, the temperature of the bath was $72^{\circ} \mathrm{C}$., when the tubes were plunged in and kept at that temperature for four minutes; on cooling the tubes and applying the guaiacum test no reaction occurred, while in corresponding unheated tubes . a vigorous reaction was soon evident.

The action of the enzyme tannase (secreted by Aspergillus niger and Penicillium spp.), which has been investigated by Fernbach (10), Pottevin (22), and Knudson (13), is one of hydrolysis, tannic acid being hydrolysed to gallic acid. The enzyme secreted by Monilia cinerea is therefore quite different from tannase, and is probably more nearly related to the oxidase found by Thatcher (25) in apples and that described by Crocker and Harrington (7) as occurring in the 'seeds' of certain grasses.

The experiments just described suggested the procedure finally adopted in investigating the oxidizing activities of the strains of Monilia which had been isolated and cultivated, a comparative study of those strains which had been used in the inoculation experiments on apple flowers carried out in I9I 8 being particularly desirable. The general method employed in this series of experiments was one which eliminated as far as possible differences due to variations in environmental factors and in manipulation. Thus throughout the series the following points were observed:

I. The same nutrient medium was used for all the experiments with the exception of Expt. 8.

2. The cultures to be tested were started from vigorously growing mycelium taken from the edge of young agar cultures.

3. The cultures were grown in Petri dishes $8.5 \mathrm{~cm}$. in diameter (internally) and 20 c.c. of the culture liquid were used in each.

4. The cultures were incubated at $25^{\circ} \mathrm{C}$. for seven days, the oxidase test being applied on the seventh day.

The culture medium was an extract of dried peaches. The apple extract used in previous experiments was rejected because of the coagulation of the pectin under the action of the fungi, the coagulum rendering the pipetting of small quantities of the liquid troublesome and inaccurate. Uschinsky's solution and a synthetic medium which Coons (6) found to be suitable for Plenodomus fuscomaculans both gave far less vigorous growth than fruit extracts in the case of the Monilias. Prunes, which had been 
generally used as a useful nutrient substrate for agar cultures, were unobtainable at the time the experiments were started, but dried peaches were available and these gave good results.

Two grammes of the dried fruit were weighed out for every Ioo c.c. of the liquid required, cut up into small pieces, and extracted with Ioo c.c. of distilled water in a steam sterilizer at $100^{\circ} \mathrm{C}$. for one hour. The extract was filtered and transferred to test-tubes, 20 c.c. to each, which were then plugged with cotton-wool and sterilized by heating at $100^{\circ} \mathrm{C}$. for 20 minutes on each of three successive days. The Petri dishes were sterilized by dry heat at $160^{\circ} \mathrm{C}$. for one hour. When cultures were to be started the contents of the tubes were emptied, with the usual precautions to avoid contamination, into the respective dishes; these were inoculated by transferring to each a small portion of the mycelium from the edge of a vigorously growing agar culture. The dishes were then placed in a thermostat at $25^{\circ} \mathrm{C}$. Thus the conditions under which the cultures were grown were the same for all the experiments, and a comparison could be made of the behaviour of strains cultivated at different times. Each experiment consisted of the culture and subsequent testing for oxidase of from 4 to 7 strains, both apple and Prumus strains being included in every experiment. After 7 days' growth the liquid contents of each plate were poured off into wide test-tubes, from which the liquid was withdrawn as required for the oxidase tests.

Reynolds Green (11) says, in reference to the guaiacum test, 'most investigators do not find it give entirely satisfactory results'. Woods (26), however, states 'that with proper care it is the best reagent which we have' for the detection of oxidizing enzymes. It has been used throughout this series of experiments, but, with the exception of No. I, the results have always been checked and confirmed by testing simultaneously for the reaction with pyrogallic acid. The guaiacum emulsion was prepared by soaking Io grm. of gum guaiacum in 100 c.c. of 95 per cent. alcohol, with occasional shaking, for several days before using ; 5 c.c. of this tincture were shaken up with 95 c.c. distilled water to make 100 c.c. of the white emulsion, which was prepared fresh for each experiment. The pyrogallic acid was used as a 2 per cent. solution prepared immediately before use.

The following details of Expt. 6 (see table on page I $^{\mathrm{I}}$ ) of this series will serve as an example of the method adopted in applying the tests.

\section{EXPERIMENT 6.}

Four strains were used in this experiment:
A. From an apple spur.
B. From an apple canker.
C. From a mummied cherry.
D. Strain from Oregon. 
When the cultures were seven days old the liquid was poured off into wide test-tubes labelled to correspond with the strains. For each strain six narrow tubes ( $\mathrm{I} \mathrm{cm}$. internal diam.) were prepared and numbered $\mathrm{I}$ to 6 . Into each of Nos. I, 2, and 3 was run (with a graduated pipette) I c.c. of the culture medium and into Nos. 4,5 , and 6 were run 2 c.c. of the medium; the colour change in the pyrogallic acid not being so striking as in guaiacum emulsion, the larger volume was used for this reagent. Tubes 3 and 6 were next heated in a water-bath at $100^{\circ} \mathrm{C}$. for two minutes and allowed to cool. Into tubes I, 2 , and 3 were now run 5 c.c. of the guaiacum emulsion and into 4,5 , and 6 five c.c. of the 2 per cent. pyrogallic acid solution. The tubes were then placed in a thermostat at $25^{\circ} \mathrm{C}$., examined from time to time, and the colour changes noted. In the guaiacum emulsion the change in colour corresponded very closely to the series of tones in Ridgway's colour scheme (23) on Plate XXXV, 49" Blue, and that series was used in naming the colours.

\section{(a) Guaiacum Emulsion as Reagent.}

Results in tubes $I$ and 2.

Time. $\quad$ A . B. $\quad C . \quad D$.

Io min. no change noticeable almost pearl blue no change pearl blue

30 min. almost pearl blue deeper than pearl ditto pale Windsor blue

I hour deeper than pearl pale Windsor blue ditto almost light Windsor

2 hrs. deeper than pale almost light Wind- ditto blue ditto

$3 \mathrm{hrs}$. Windsor blue $\quad \begin{gathered}\text { sor blue } \\ \text { light Windsor blue }\end{gathered}$

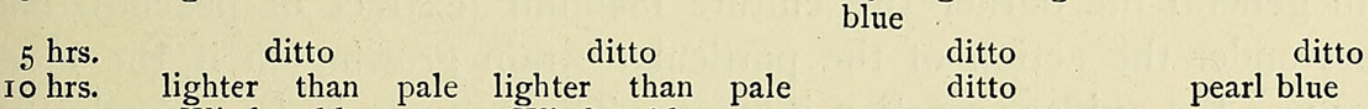

$\begin{array}{llllr}\text { Io hrs. lighter than pale lighter than pale } & \text { ditto } & \text { pearl blue } \\ & \text { Windsor blue } \\ 24 \mathrm{hrs} . & \text { lighter than pearl lighter than pearl colour a little more } & \text { ditto }\end{array}$

$24 \mathrm{hrs}$. lighter than pearl lighter than pearl colour a little more
blue blue $\begin{gathered}\text { distinct but } \\ \text { still }\end{gathered}$

$48 \mathrm{hrs}$. almost decolorized almost decolorized very faint tint almost decolorized

Tube No. 3 in each case remained unchanged throughout the experiment.

(b) 2 per cent. Pyrogallic Acid as Reagent.

Results in tubes 4 and 5 .

\begin{tabular}{|c|c|c|c|c|}
\hline $\begin{array}{l}\text { Time. } \\
\text { o min. }\end{array}$ & $\begin{array}{r}A . \\
\text { no change }\end{array}$ & no change & no change & $D$. \\
\hline $\operatorname{mil}$ & very slightly yel- & distinctly yellower & not distinguishable & llower but \\
\hline $\begin{array}{l}\text { hou } \\
\text { hrs }\end{array}$ & $\begin{array}{l}\text { very pale yellow } \\
\text { pale yellow }\end{array}$ & $\begin{array}{l}\text { pale yellow } \\
\text { colour more distinct }\end{array}$ & $\begin{array}{l}\text { ditto } \\
\text { ditto }\end{array}$ & $\begin{array}{c}\text { colour more distinct } \\
\text { ditto }\end{array}$ \\
\hline $\mathrm{ars}$ & & bright yellow & dit & bright yellow \\
\hline & bright yellow & ditto & dit & ditto \\
\hline & $\begin{array}{l}\text { deep brownish yel- } \\
\text { low ditto }\end{array}$ & $\begin{array}{l}\text { very deep brownish } \\
\text { yellow } \\
\text { ditto }\end{array}$ & ditto & $\begin{array}{l}\text { very deep brownish } \\
\text { yellow ditto }\end{array}$ \\
\hline
\end{tabular}


All the tubes at first showed a very faint yellowish tint owing to the colouring matter present in the culture medium. Tube No. 6 of each strain showed a very gradual deepening of the tint due to the slow oxidation of the pyrogallic acid, which normally darkens when in solution in contact with the air, but after 24 hours all the four tubes were still a very pale yellow and the tint was but slightly deeper after 48 hours.

The following table gives a resumé of the results obtained for all the strains of Monilia tested in this series of experiments. The numbers indicate the maximum colour change which developed in each case; the values of these numbers in the guaiacum test are as follows:

I. indicates a faint bluish tint.

2. corresponds to pearl blue.

3. " $\quad$ pale Windsor blue.

4. " light Windsor blue.

5. " $\quad$ clear Windsor blue.

The colour changes in the pyrogallic acid could not be so readily defined, the transparent liquids not being suitable for use with the colour chart. I, however, indicates a very slight yellowing just discernible when the tubes were carefully examined side by side with the control (heated) tube, while 5 denotes a deep brownish yellow. In Expt. I tannic acid was used instead of pyrogallic acid.

As in the case of the apple extract, it was found in these experiments that in general the darker the culture medium (extract of peaches) had become under the action of the particular strain growing in it, the more intense was the oxidase reaction it gave. The cultures in Coons' solution, however, all remained colourless, and as the results obtained in the tests, though essentially confirming those obtained with the fruit extracts, showed some variation in detail from the rest of the series, the results are given fully. 


\section{EXPERIMENT 8.}

Strains grown in Coons' Solution.
A. From an apple spur.
B. From a mummied cherry.
C. From a plum twig affected with the 'Wither Tip' disease.
D. A strain from America (Oregon).
E. Another strain from America (Ontario).

(a) Guaiacum Emulsion as Reagent.

Results in tubes I and 2.

\begin{tabular}{rlcccc} 
Time. & \multicolumn{1}{c}{$A}$. & $B$. & $C$. & $D$. & $E$. \\
2 hrs. & slight bluish tint & no change & no change & no change & pearl blue \\
4 hrs. & deeper than pearl blue & ditto & ditto & ditto & clear Windsor blue \\
8 hrs. & deeper than pale Windsor blue & ditto & ditto & ditto & ditto \\
24 hrs. & light Windsor blue & ditto & ditto & pearl blue & ditto
\end{tabular}

(b) 2 per cent. Pyrogallic Acid as Reagent.

$\begin{array}{rlllll}\text { Time. } & A . & B . & C . & D . & E . \\ 2 \text { hrs. } & \text { very pale yellow } & \text { no change } & \text { no change } & \text { no change } & \text { very pale } \\ 4 \text { hrs. } & \text { pale yellow } & \text { ditto } & \text { ditto } & \text { very pale yellow } & \text { pale yellow } \\ 8 \text { hrs. } & \text { ditto } & \text { ditto } & \text { ditto } & \text { ditto } & \text { ditto } \\ 24 \text { hrs. } & \text { bright yellow } & \text { ditto very pale yellow } & \text { bright yellow } & \text { deep yellow }\end{array}$

In Coons' solution the growth of the strains was comparatively feeble, the diameter of the mycelial discs at the end of seven days being only about half that of the cultures of the same age in the fruit extracts, and the hyphae were less densely interwoven. The oxidizing reaction of the cultures was more gradual than in the other experiments of the series, and the pyrogallic acid proved to be the more sensitive of the two reagents.

The dark coloration developed in the fruit extracts when certain strains of Monilia cinerea are growing in them is, in all probability, due to the oxidation of tannins, present in the extracts, by the oxidase secreted by the fungus. That the presence of tannins is not a factor necessary for the secretion of the oxidase is shown by the cultures grown in Coons' solution, a medium consisting of inorganic salts, asparagin, and glucose.

It was found in every experiment that the strains of Monilia cinerea from apple trees produced the oxidase far more readily than those from other sources, with the exception of the American strains, which appear to belong to a distinct variety, if not species. This is correlated with their power of infecting apple flowers; five of the strains which have given no oxidase reaction, or a very feeble one, have been used in the inoculation experiments on apple flowers, and all failed to produce the blossom wilt condition which is typical of infection by the apple strains. 
Wormald.-Brown Rot' Diseases of Fruit Trees. II. I53

(b) The Enzyme in Infected Apples.

It has already been shown (30) that infection of apples with an apple strain and with a plum strain of Monilia cinerea gave different results, the latter causing a brown rot, while with the former the brown colour gradually assumed a darker tone and eventually became black. The enzyme experiments just described suggested that the differences might be due to the oxidase secreted by the apple strain. To verify this the following experiments were made:

\section{EXPERIMENT I.}

On October 26, 1917, four apples were inoculated, two with an apple strain and two with a Wither Tip strain from a plum tree. On Nov. 30 the former were black, the latter a bright brown. From each of the four apples a cube of tissue (side of cube $5 \mathrm{~mm}$.), including the skin, was cut out at $\mathrm{I} \cdot 5 \mathrm{~cm}$. from the point of inoculation and ground up with a few c.c. of distilled water in a mortar; more water was then added to make up to 6 c.c., and 3 c.c. were poured into each of two test-tubes. 2 c.c. of guaiacum emulsion were added to each tube and all were incubated at $30^{\circ} \mathrm{C}$. Two control tubes were also prepared from a cube of tissue similarly cut from a sound apple and extracted.

The oxidase reaction was greatest in the tubes containing the extract of the apple infected with the apple strain; the other tubes (including the controls) also gave the reaction, but the colour change was feebler.

\section{EXPERIMENT 2.}

The strains were those used in Expt. I. An apple was inoculated on Nov. 28 on one side with the apple strain, and on the other with the plum strain. By Dec. I I both strains had caused a discoloration of the surface, but there was still a strip of healthy tissue midway between the two infected areas. Six cubes of tissue (side of cube $5 \mathrm{~mm}$.) were cut out of the apple, viz. :

(I) from the side infected with apple strain, at $\mathrm{I} \mathrm{cm}$. from the edge of the discoloured area ;

(2) as (I), but at $2 \mathrm{~cm}$. from edge of discoloured area ;

(3) from the side infected with plum strain, at $I \mathrm{~cm}$. from the edge of the affected area ;

(4) as (3), but at $2 \mathrm{~cm}$. from edge ;

(5) $(6)$ from the healthy portion of the same apple.

Each cube of tissue was ground in a mortar with a little distilled water, and more water was then added to make up to 5 c.c.; this was divided into 


\section{I54 Wormald.- 'Brown Rot' Diseases of Fruit Trees. II.}

two parts by pouring 2.5 c.c. into each of two test-tubes. Io c.c. of the guaiacum emulsion were added to each tube. Result :

\begin{tabular}{|c|c|c|c|c|c|c|}
\hline \multirow[b]{2}{*}{ Time. } & \multicolumn{2}{|c|}{$\begin{array}{c}\text { From side infected with apple } \\
\text { strain. }\end{array}$} & \multicolumn{2}{|c|}{$\begin{array}{l}\text { From side infected with plum } \\
\text { strain. }\end{array}$} & \multicolumn{2}{|c|}{ From healthy portion. } \\
\hline & $\begin{array}{l}(\mathrm{I}) \\
2 \text { tubes }\end{array}$ & $\begin{array}{l}(2) \\
2 \text { tubes }\end{array}$ & $\begin{array}{l}(3) \\
2 \text { tubes }\end{array}$ & $\begin{array}{l}(4) \\
2 \text { tubes }\end{array}$ & $\begin{array}{l}(5) \\
2 \text { tubes }\end{array}$ & $\begin{array}{c}(6) \\
2 \text { tubes }\end{array}$ \\
\hline $\begin{array}{l}\text { I hr. } \\
2 \mathrm{hrs} \text {. } \\
\text { Io hrs. }\end{array}$ & $\begin{array}{l}\text { bright blue } \\
\text { deep blue } \\
\text { ditto }\end{array}$ & $\begin{array}{l}\text { bright blue } \\
\text { deep blue } \\
\text { a little paier }\end{array}$ & $\begin{array}{l}\text { pale blue } \\
\text { ditto } \\
\text { nearly decolor- } \\
\text { ized }\end{array}$ & $\begin{array}{l}\text { very pale blue } \\
\text { pale blue } \\
\text { very pale blue }\end{array}$ & $\begin{array}{l}\text { no change } \\
\text { ditto } \\
\text { ditto }\end{array}$ & $\begin{array}{l}\text { no change } \\
\text { ditto } \\
\text { ditto }\end{array}$ \\
\hline 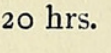 & verv pale bl & very & $\mathrm{de}$ & & dit & dit \\
\hline
\end{tabular}

\section{EXPERIMENT 3 .}

This was carried out as in Expt. 2, using another apple similarly inoculated. The results were essentially the same as those of Expt. 2 ; the control tubes (containing extract of sound tissue) again gave no oxidase reaction, the tubes of the apple strain gave a vigorous reaction, and those of the plum strain a feeble one (see Fig. 8).

\section{EXPERIMENT 4.}

From the same apple as used in Expt. 2 cubes of tissue were cut from infected and healthy portions and extracted, but instead of guaiacum a 2 per cent. solution of tannic acid was used as the reagent. Again the reaction was greatest in those tubes containing the extract of tissue infected with the apple strain, slight in those with the plum strain, and not discernible in the control tubes.

The absence, in these experiments, of any reaction in the tubes containing the extract of the uninfected portions of the apples calls for remark, since Lindet (15) and Thatcher (25) find that apple juice contains an oxidase which acts on tannins. It is clear, however, that, in the experiments recorded above, if an oxidase were present in the tissues of the apples its action was so feeble that it could not be detected by the method adopted, but this in no way affects the comparative results, which show that an active oxidase was secreted by the apple strain of Monilia cinerea when parasitic within the tissues of the apples.

The conclusion is that the blackening of the apples infected with Monilia cinerea forma mali is correlated with the secretion by the fungus of an enzyme which oxidizes tannin, and the nigrescence is probably the result of the oxidation of tannins in, or immediately below, the skin.

\section{(c) The Ensyme in Infected Apple Spurs.}

The preceding experiments, which show that the 'Blossom Wilt' Monilia of apple trees produces in liquid culture media and in infected apples an enzyme which rapidly oxidizes tannins, suggested that the same 
enzyme might be secreted when the fungus is invading the tissues of apple spurs. Experiments were therefore carried out with the object of determining whether that or a similar enzyme could be detected in infected spurs.

\section{EXPERIMENT I.}

In this preliminary experiment a dead spur showing typical blossom wilt was obtained from a Lord Derby apple tree in the College plantation ; the current year's growth (which was not yet fully lignified and therefore softer than the woody portion of the previous year) was cut off and the dead leaves and flowers removed. This short shoot, about $1.5 \mathrm{~cm}$. in length, was pounded with about I c c. of water and ground in a mortar to a paste, which was washed out with a little more water into a test-tube and finally made up to 5 c.c. This extract was allowed to stand for a few minutes until the grosser particles sank to the bottom ; the liquid above was then poured off and I c.c. of it was transferred by means of a pipette to each of three testtubes. One tube was heated in a water-bath at boiling-point for two minutes and cooled; then to each of the three tubes were added 5 c.c. of guaiacum emulsion and the tubes were placed in an incubator at $25^{\circ} \mathrm{C}$. Tubes I and 2 (unheated) gradually assumed a bluish tint, and after three hours were a pale blue; in the third tube no change occurred. It appeared evident that an oxidase could be extracted from an infected spur, so other experiments were carried out to ascertain whether this enzyme was similar in action to that secreted by the fungus when growing in liquid culture media, and also whether it occurred exclusively in infected spurs.

\section{EXPERIMENT 2.}

An extract was obtained from another infected spur as in Expt. I and a normal (living) spur was also extracted for comparison. Three tubes of each extract were prepared as in the previous experiment, one of the three being heated before adding the guaiacum emulsion, and all were placed in the thermostat.

The emulsion rapidly became coloured in the tubes containing the extract of the living spur, but the colour was much greener than in those tubes containing the infected material; the latter were coloured more slowly, but eventually were approximately of the same tone as that obtained when using the liquid from pure cultures.

The contrast between the two sets of tubes was very marked after 24 hours :

Extract of infected spur (unheated) and guaiacum emulsion : bright blue (approx. 'Russian Blue' of Ridgway's scheme).

Extract of normal spur (unheated) and guaiacum emulsion: bright green (approx. 'Deep Grape Green').

Both tubes containing the heated extract remained unchanged. 


\section{EXPERIMENT 3 .}

This was a repetition of Expt. 2, using two other spurs-one infected and the other normal. The result was practically the same.

\section{EXPERIMENT 4.}

This was carried out as Expts. 2 and 3, except that the spurs were taken from another variety of apple tree, viz. James Grieve, those used in the previous experiment having been taken from a tree of the Lord Derby variety ; the method, too, was slightly modified, the extracts being prepared as before and then centrifugalized to give a clearer solution.

The result again was as before.

\section{EXPERIMENT 5.}

Extracts were prepared of two infected and two normal spurs and centrifugalized; those of one infected and one normal spur were filtered through Swedish filter-paper. The extracts were then tested for their reaction with the guaiacum emulsion and with pyrogallic acid. Since the slight turbidity of the centrifugalized extracts was not removed by filtering, and as the results obtained with filtered and unfiltered extracts of similar spurs were identical, the filtering was not repeated in subsequent experiments.

Tubes of each of the four extracts were prepared, I c.c. of the extract being placed in each, with 5 c.c. of the reagent, viz. :

I. Guaiacum emulsion.

2. " " control (i.e. the extract being previously heated). 3. 2 per cent. pyrogallic acid.

4. " " "

5. " " " control (extract heated).

Result in unheated tubes :

\begin{tabular}{|c|c|c|c|c|}
\hline \multirow[b]{2}{*}{ Time. } & \multicolumn{2}{|c|}{ Guaiacum emulsion. } & \multicolumn{2}{|c|}{ Pyrogallic acid. } \\
\hline & Infected spur. & Normal s, & $d c$ & Normal spur. \\
\hline & $\begin{array}{l}\text { bright blue } \\
\text { pale blue }\end{array}$ & $\begin{array}{l}\text { no change } \\
\text { pale buff yellow }\end{array}$ & $\begin{array}{l}\text { no c } \\
\text { deep }\end{array}$ & ditto \\
\hline
\end{tabular}

The control tubes of guaiacum emulsion remained unchanged; a slight yellowing of the pyrogallic acid control tubes was the result of the usual oxidation of the acid in solution when in contact with the air.

Expts. 6 and 7 were carried out as in Expt. 5, except that the filtering was omitted, and that the infected spurs used were those which had been infected by artificial inoculation from pure cultures of apple Blossom Wilt strains which are included among those that have been proved to produce the enzyme when growing in liquid culture media (Strains I, 2, 3, and 8 of table on page ${ }_{5}$ I). 
The results were the same as those in Expt. 5, except that the extracts of normal spurs gave a more distinct yellow colour to the pyrogallic acid solution.

It will be observed that in the earlier experiments of this series (Expts. I-4), which were carried out from May 24 to 28 , the extracts of normal spurs invariably produced a bright green coloration of the guaiacum emulsion, while later experiments (5-7), carried out from May 29 to June 7 , failed to produce the green coloration of the emulsion and extracts of normal spurs gave only a buff yellow. It seemed probable that this yellow colour was due to a change occurring in the extract itself which imparted a tint to the mixture without any reaction with the emulsion. In this case the green colour of the earlier experiments might have been the result of an oxidase reaction with the emulsion to produce a blue which, mixed with the yellow extract, would give a green.

That the green colour can be reproduced in this way was shown by Expts. 8 and 9 .

\section{EXPERIMENT 8.}

A tube was prepared by mixing

I c.c. of an extract of an infected spur,

I c.c. of an extract of a normal spur,

5 c.c guaiacum emulsion.

After incubating for 4 hours at $25^{\circ} \mathrm{C}$. the contents of the tube were a bright green.

\section{EXPERIMENT 9.}

Three tubes were prepared as follows :

( I) I c.c. of extract from infected spur + I c.c. distilled water.

(2) I c.c. extract from infected spur + I c.c. extract of normal spur.

(3) I c.c. extract normal spur + I c.c. distilled water.

5 c.c. of guaiacum emulsion werc added to each and the tubes were incubated. At end of 20 hours the contents were

(I) pale blue;

(2) bright green;

(3) buff yellow.

In order to ascertain whether the yellow pigment which was produced in the extracts of normal spurs could be detected in extracts of infected spurs, another experiment was carried out.

\section{EXPERIMENT IO.}

Extracts were made of infected and normal spurs and centrifugalized; each was divided into two portions, one of which was heated for one minute in a water-bath at $100^{\circ} \mathrm{C}$. and the other left unheated. The tubes were then incubated without the addition of any reagent. 


\section{I58 Wormald.- 'Brown Rot' Diseases of Fruit Trees. II.}

Result :

$\begin{array}{rcccc} & \text { Extract of infected spur. } & \text { Extract of normal spur. } \\ & \text { Unheated. } & \text { Heated. } & \text { Unheated. } & \text { Heated. } \\ 4 \mathrm{hrs} . & \text { no change } & \text { no change } & \text { deep yellow } & \text { no change } \\ 24 \mathrm{hrs} . & \text { ditto } & \text { ditto } & \text { ditto } & \text { very pale yellow }\end{array}$

The result was confirmed in three other similar experiments. The freshly made extracts, after being centrifugalized, were in each case almost colourless, but with slight turbidity.

\section{EXPERIMENT II.}

In this experiment the action of the enzyme in an infected spur on the chromogenic substance of the normal spur was examined. A normal spur was extracted with Io c.c. distilled water; this extract was centrifugalized and then heated in a water-bath for 5 minutes. Two tubes were set up as follows :

(I) 5 c.c. of this extract + I c.c. of unheated extract of an infected spur.

(2) 5 c.c. of this extract + I c.c. of heated extract of an infected spur.

The tubes were incubated at $25^{\circ} \mathrm{C}$. At the end of 8 hours the contents of both tubes were distinctly yellow, but the liquid in (I) was of a deeper colour than that of (2).

The experiment was duplicated, using two other spurs, and a similar result was obtained.

It would seem, then, that an extract of a normal spur contains a substance which darkens in colour on contact with air, but that the process is hastened by the enzyme (found in infected spurs) secreted by the fungus.

The results of these experiments lead to the following conclusions :

(I) That in the extract of a normal (healthy) flowering spur of apple trees there is present some substance, probably a tannin, which assumes a deep yellow colour when the extract remains in contact with the air. That this colour change is in part due to enzyme action is suggested by the fact that the action is retarded when the extract has been previously heated, but such an enzyme, if present, gives no reaction with guaiacum. In addition there is evidence that flowering spurs also contain an oxidase (reacting with guaiacum) at about the time the flowers are setting into fruit, but that later it cannot be detected.

(2) That in an infected spur there is present an enzyme which reacts with guaiacum and oxidizes pyrogallic acid.

(3) That the chromogenic tannic substance present in a spur is oxidized, on infection, by the enzyme secreted by the fungus, so that the centrifugalized extract of the infected spur no longer contains the tannin, which must therefore have been either assimilated by the fungus or deposited in the tissues in an insoluble form.

Thus that form of Monilia cinerea (referred to in this paper as forma 
mali) which causes a blossom wilt and canker disease of apple trees secretes an enzyme, easily detected in liquid culture media, in infected apples, and in infected flowering shoots; this enzyme responds to the guaiacum test and accelerates the absorption of oxygen by tannins.

The fact that those strains of Monilia cinerea which in inoculation experiments were unable to cause a blossom wilt of apples secrete this enzyme far less readily suggests that the virulence of the apple form may be due to this property of secreting an enzyme capable of acting on substances present in the tissues of the host plant.

In this connexion it is to be noted that Percival (21), in his investigations on the 'Silver Leaf' disease of fruit trees, found that the disease was associated with the presence of an oxidase which is easily extracted from diseased tissues; later, however, Brooks (5) stated that ' until the present I have been unable to confirm Percival's view that the disturbing agent is an oxidase which is secreted by the fungus'.

Whether the secretion of an oxidase is a factor determining the degree of virulence of the Brown Rot fungi is yet to be determined, but the fact that two biologic forms morphologically similar are in some respects physiologically distinct under laboratory conditions is of considerable interest, and further investigations along these lines may throw some light on the mode of parasitism of such biologic forms.

\section{MORPHOLOGY AND TAXONOMY.}

\section{(a) Colour and Size of Pustules.}

When Monilia fructigena and $M$. cinerea are growing under the same conditions, they can, as a rule, be readily distinguished by their conidial fructifications. Thus the pustules of the former are larger than those of the latter and are yellow in colour, while the pustules of $M$. cinerea are, as its specific name implies, ashy grey. These characters may, however, show some variation according to the conditions under which the fructifications are produced. The difference between the two is most striking when they are growing vigorously on recently infected fruit. Thus in an experiment where plums were simultaneously inoculated with the two species, $M$. fructigena produced pustules of a maximum diameter of $\mathrm{I} \cdot 5 \mathrm{~mm}$. (mostly about I mm.) and 'Light Buff' ' in colour, while those of $M$. cinerea only reached a maximum diameter of $0.8 \mathrm{~mm}$. (mostly about $0.4 \mathrm{~mm}$.) and were 'Smoke Grey' ${ }^{\prime}$ in colour. The pustules had, in this instance, developed during a period of dry weather and were on that account comparatively small. ${ }^{2}$ When produced in a moist atmosphere the pustules are larger, but the relative size for the two species remains approximately the same. ${ }^{3}$ Pustules of $M$. cinerea on apple spurs and cankers may under favourable conditions

1 Ridgway's scheme of colours.

2 Vide Part I, Figs. 8 and 9. 
reach a diameter of $\mathrm{I} .5 \mathrm{~mm}$., while $M$. fructigena when growing on maturing apples and on apple spurs frequently produces pustules $2 \mathrm{~mm}$. in diameter.

Old pustules of $M$. cinerea when redeveloping on mummied plums in winter and spring often coalesce, and from their general appearance at that time of the year might easily be mistaken for $M$. fructigena (cf. Figs. 2 and 3 ).

\section{(b) Dimensions of Conidia.}

The dimensions of the conidia of the two species are generally quoted as a distinguishing character. The great variation in the size of the conidia of $M$. cinerea according to the conditions under which they are developed renders this distinction somewhat unreliable unless the environmental factors are taken into consideration. This point has been discussed in previous papers in connexion with strains occurring on apple trees and plum twigs; it was there shown that the average size of Ioo conidia of each of a number of strains of $M$. cinerea found on cankers, spurs, twigs, and mummied plums was from II.O $\times 8.0 \mu$ to $I 2.0 \times 8.5 \mu$, but when the strains were grown on fruit in summer or on sterilized potato in the laboratory the dimensions of the conidia were about one and a half times as great.

Further observations and experiments have confirmed those results as shown in the following tables. In each case the conidia were mounted in distilled water; Ioo were then measured and the average determined. To avoid unconscious selection, small groups were taken and all the conidia of each group measured, though isolated conidia occurring between the groups were also included; the range of variation was obtained by examining the whole of a slide and selecting for measurement the largest and smallest that could be found. The readings were taken correct to $0.5 \mu$ and the averages were calculated and recorded also correct to the nearest $0.5 \mu$.

\section{Dimensions of Conidia of Monilia cinerea.}

Source of Conidia.
Apple tree-Brown Rot canker
Apple spur
Apple tree-Brown Rot canker
Apple twig
Plum twig (Kent)
Mummied plum (Cambridge)
Mummied plum (Worcestershire)
Mummied plum (Devonshire)
Mummied cherry (Kent)
$\quad$ ditto ditto
Plum (Ireland)
Plum (Kent)
Plum (Kent)

\section{Date. Range of Variation.}

Mar. 8- $6.5 \times 5.0-14.0 \times 8.5 \mu$

Apr. $5 \quad 6.0 \times 4.5^{-15.5} \times 12.5$

June $198.0 \times 6.0-19.0 \times 12.5$

June $298.0 \times 7.5-22.5 \times 14.5$

Mar. I $45.0 \times 4.0-17.0 \times 11.5$

Mar. $196.0 \times 5.0-19.0 \times 11.5$

Apr. $8 \quad 5.0 \times 4.0-17.5 \times 10.5$

Apr. $8 \quad 7.0 \times 5.0-18.5 \times 11.0$

Mar. $4 \quad 6.0 \times 5.0-15.0 \times 11.0$

Apr. $197.0 \times 5.5^{-21} .0 \times 15.0$

Aug. $2 \quad 10.5 \times 7.0-27.5 \times 16.5$

Sept. $8 \quad 9.5 \times 7.0-23.0 \times 15.0$

Sept. $158.5 \times 6.5-22.5 \times 18.0$

$$
\begin{aligned}
& \text { Average. } \\
& \text { I0.5 } 57.5 \mu \\
& \text { II } .5 \times 8.5 \\
& \text { I } 3.5 \times 9.5 \\
& \text { I } 4.0 \times 10.5 \\
& \text { I } 1.5 \times 8.5 \\
& \text { I } 1.5 \times 8.0 \\
& \text { II } .5 \times 7.5 \\
& \text { I } 1.5 \times 8.0 \\
& \text { II } .5 \times 8.0 \\
& \text { I } 3.0 \times 10.0 \\
& \text { I } 8.5 \times 11.5 \\
& \text { I } 6.5 \times 9.5 \\
& \text { I } 7.0 \times 10.5
\end{aligned}
$$

That this difference in the average size of the conidia was due to environmental factors was shown by cultivating certain strains under various conditions and noting the variation induced by transferring any one strain from one set of conditions to another. A strain found on a mummied 


\section{Wormald.- 'Brown Rot' Diseases of Fruit Trees. II. I6 I}

cherry in March bore conidia of which the average size was II $\cdot 5 \times 8.0 \mu$; when isolated and grown on a young plum in the following July the average was $18.0 \times 13.0 \mu$. The corresponding figures for a strain found on a mummied plum and later grown on a young plum were $\mathrm{I} 1.5 \times 8.0 \mu$ (March) and $19.0 \times 13.5 \mu$ (July).

A strain isolated from a plum twig gave the variation in the average size of its conidia shown in the following table:

Conditions under which the Conidia
were produced.

Plum twig

Plum inoculated from pure culture ditto ditto

Culture on sterilized potato in laboratory

Mummied plum, result of inoculation in previous year
Date.

Mar. 27, I917

July I8, I9I 7

July 3 I, I9I 7

Nov. I9, I9I

Feb. 28, I918
Range of Variation. $5.5 \times 5.0-14.5 \times 9.0 \mu$
$10.0 \times 7.5-27.0 \times 19.5$
$10.0 \times 7.5-27.0 \times 14.5$
$7.5 \times 6.0-25.0 \times 18.5$

$6.5 \times 5.0-16.5 \times 1 \mathrm{I} \cdot 5$
Average.

$10.5 \times 7.0 \mu$

$16.5 \times 12.5$

$16.0 \times 11.0$

$16.5 \times 12.0$

$12.0 \times 8.5$

The most convincing proof of this polymorphism of the conidia was furnished by the strain already referred to as being isolated from a Brown Rot canker of an apple tree in 1916 and used in inoculation experiments on apple flowers during three successive seasons; the results are here tabulated:

Conditions under which the Conidia were produced.

Brown Rot canker

Culture on sterilized potato in laboratory

Pedicel of apple flower inoculated from pure culture in May, I9 6

Dead spur, result of inoculation from pure culture in May, I9I6

Pedicel of apple flower inoculated May I7, I9I7

Dead spur, result of inoculation in May, 1916

Plum inoculated from pure culture on June 24, 1918
Date.

Apr. I5, 19I6

May 5, I9I6

July I I, I9I 6

Feb. I3, I9I7

May 30, I9I 7

Mar. 22, x9I 8

July 4 , I9I 8
Range of Variation.

$7.0 \times 6.0-14.0 \times 10.5 \mu \quad \mathrm{II} .0 \times 8.0 \mu$ $9.0 \times 7.0-26.0 \times 20.0 \quad 18.0 \times 13.5$

$9.0 \times 7.0-21.5 \times 15.0$

I $5.5 \times 12 \cdot 0$

$6.0 \times 5.0-15.0 \times 10.5$

I I $.0 \times 8.5$

$14.0 \times 11.0-26.0 \times 19.5$

$18.0 \times 14.5$

$6.0 \times 4.0-16.0 \times 11.5$

I I. $5 \times 8 \cdot 5$

$9.5 \times 8.0-26.5 \times 20.0$

$19.0 \times 14.0$

That the nature of the substratum on which a fungus is growing may determine the size of the conidia has been observed by Neger (19) in certain Erysiphaceae and by Brierley (4) in Botrytis cinerea.

The seasonal variation in the dimensions of the conidia, which is so striking in Monilia cinerea, is much less noticeable in the case of Monilia fructigena, which produces conidia freely only during the warmer months of the year. In general the conidia of $M$. fructigena are larger than those of $M$. cinerea:

\section{Dimensions of Conidia of Monilia fructigena.}

\section{Source of Conidia.}

Mummied apple, old pustules redeveloping Plum, recently infected

Apple, ", "

Plum, ", ",

Fruiting spur of apple
Date.

June 26

July I 7

Oct. 25

Sept. I 8

Aug. 29

Sept. Io

M 2

\section{Range of Variation.}

$\mathrm{I} 1.0 \times 9.5^{-26.5} \times 16.0 \mu$ I $2.0 \times 8.5-31.0 \times 16.0$ $13.0 \times 9.0-28.0 \times 16.5$ I $2.0 \times 9.0-27.5 \times 15.0$ $12.5 \times 9.5-31.0 \times 17.5$ I $4.5 \times 11.0-29.0 \times 17.0$

\section{Average.}

$19.0 \times 12.5 \mu$

$2 \mathrm{I} .5 \times 13.0$

$20.5 \times 13.5$

$20.0 \times 12.5$

$24.5 \times 13.5$

$23.5 \times 14.0$ 
That the conidia of Monilia fructigena are appreciably larger than those of $M$. cinerea when produced under the same conditions was determined by measuring the conidia of the two species (1) when both were found growing on different plums of the same cluster, and (2) when both were growing on the same plum which had been inoculated on opposite sides with the two species.

Dimensions of Conidia of $M$. fructigena and $M$. cinerea.

(I) On different plums of the same cluster.

\begin{tabular}{lcrc}
\multicolumn{1}{c}{ Species. } & Date. & Range of Variation. & \multicolumn{1}{c}{ Average. } \\
$\begin{array}{l}\text { M. fructigena } \\
\text { Sept. } 18\end{array}$ & $12.0 \times 9 \cdot 0-27.5 \times 15^{\circ}{ }^{\mu}$ & $20.0 \times 12 \cdot 5 \mu$ \\
cinerea & Sept. 17 & $8.5 \times 6.5-22.5 \times 18.0$ & $17 \cdot 0 \times 10.5$
\end{tabular}

(2) On opposite sides of the same plum, inoculated July I 7 .

\begin{tabular}{lccc}
\multicolumn{1}{c}{ Species. } & Date. & Range of Variation. & Average. \\
$\begin{array}{l}\text { M. fructigena } \\
\text { M. cinerea }\end{array}$ & July $3 \mathrm{I}$ & $\mathrm{I} 4.0 \times \mathrm{II} \cdot 0-34.0 \times 15 \cdot 0 \mu$ & $2 \mathrm{I} \cdot 0 \times \mathrm{I} 3.5 \mu$ \\
& $"$ & $\mathrm{I} 0.0 \times 7.5-27.0 \times 14.5$ & $\mathrm{I} 6.0 \times \mathrm{II} \cdot 0$
\end{tabular}

It follows from these results that measurements of the conidia of $M$. fructigena and $M$. cinerea aid in diagnosing the species, but when the two are grown under the same conditions it is found that the difference is not so great as is generally supposed. The dimensions of the conidia as determined by continental workers are as follows :

\begin{tabular}{|c|c|c|}
\hline Author. & M. fructigena. & M. cinerea. \\
\hline accardo & $25 \times 10-12 \mu$ & ${ }^{1} 5^{-1} 7 \times 10-12 \mu$ \\
\hline Lindau & $20-24 \times I_{2}-\mathrm{I} 4$ & I $2-13 \times 9-10$ \\
\hline $\begin{array}{l}\text { Woronin } \\
\text { Schröter }\end{array}$ & $\begin{array}{cc}\text { Average } & 20.9 \times \mathrm{I} 2 . \mathrm{I} \\
\mathrm{I} 8-24 \times \mathrm{IO}-\mathrm{I} 2\end{array}$ & 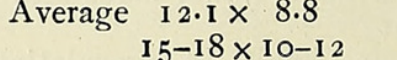 \\
\hline Aderhold and Ruhland & $18-23 \times 9-13$ & $9.3-14.5 \times 6.2-12.4$ \\
\hline
\end{tabular}

Woronin (27) found that when $M$. cinerea was growing on twigs or on the surface of various stone-fruits the average size of the conidia was I2.I $X$ $8.8 \mu$; the largest conidia he found under natural conditions measured I $3.2 \times 9.9 \mu$. It would seem from these figures that the dimensions quoted were those of conidia examined early in the year, and that the larger conidia produced on growing fruit in summer were not observed by Woronin; he found, however, that when $M$. cinerea was cultivated on artificially prepared media the average size of the conidia produced rose to I $7.5 \times$ II. $2 \mu$. Lindau and Aderhold and Ruhland also probably made their observations on conidia produced in winter, while Saccardo and Schröter must have examined summer conidia. This would explain the apparent discrepancies in the results obtained by the various workers.

In general terms the two species are to be distinguished by means of the conidia as follows :

$M$. cinerea produces in winter and early spring, on cankers, twigs, and mummied fruit, conidia the average length of which is about II $5 \mu$, 


\section{Wormald.- 'Brown Rot' Diseases of Fruit Trees. II. ${ }_{16} 6_{3}$}

while on recently infected fruit in summer the average length is about I7 $\mu$.

$M$. fructigena produces conidia freely only in summer and autumn, and their average length is from $20 \mu$ to $24.5 \mu$, according to the conditions under which they are produced.

\section{(c) Viability of the Conidia.}

During the winter months the pustules of Monilia fructigena are, as a rule, barren, as the conidia are mostly dispersed by the wind or washed away by rain in the autumn, and no others are produced until the approach of summer; those conidia still adhering to the pustules in winter are generally found to be collapsed or shrunken and incapable of germination, although particles of the pustules themselves, when placed in hanging drops of distilled water or on culture media, readily develop hyphae within 24 hours. These barren pustules differ in general appearance. Some are nonpulverulent ; these vary in colour from a pale straw colour to almost white. Others are somewhat pulverulent or velutinous and are dark brown in colour; this condition is due to the presence of a hyphomycetous fungus with brown mycelium and conidia growing on the old pustules of $M$. fructigena (see Fig. 3).

On the other hand $M$. cinerea is stimulated to the production of pustules and conidia during winter. The form which produces the Blossom Wilt of apple trees, when it invades the tissues of the flowers, flowering spurs, and branches, may produce pustules on the pedicels and floral organs of the attacked flowers soon after infection, but this is not invariably the case, and, in so far as the author's experience has gone, appears to be the exception. Generally no pustules appear on the affected organs until about the beginning of December, when pustules begin to burst through the bark of the cankers and diseased spurs, and they continue to develop throughout the winter and spring. This condition, too, obtains in the young vegetative shoots of the plum when attacked by $M$. cinerea; conidia may be produced on the affected leaves, but pustules do not appear at the surface of the axis of the shoot until the approach of winter.

When $M$. cinerea occurs on fruit, e.g. plums and cherries, numerous pustules are produced during the summer (Pl. IV, Fig. I), and, persisting on the mummified fruit, redevelop and become pulverulent during the following winter and spring (Fig. 2).

Apples which had been artificially inoculated with the apple Blossom Wilt form of $M$. cinerea in the laboratory produced no pustules, or very few, under those conditions, but when the infected black apples resulting from such inoculations were placed in the open air pustules burst through the skin and became covered with conidia during the winter.

Conidia produced at these low temperatures germinate readily when 
placed in water. In January, 1917 , during a period of severe frost, conidia of $M$. cinerea were taken from pustules growing on an apple tree in the open (the thermometer at the time showing a temperature of $-2^{\circ} \mathrm{C}$.) and mounted in a drop of water; the slide was placed in a damp chamber in the laboratory and within 24 hours $5 \circ$ per cent. of the conidia had developed germ tubes.

These observations confirm conclusions arrived at by Ewert (9), who states that 'im Winter auf den Pflaumenmumien die Sporen der M. cinerea stets lebendig, die der $M$. fructigena stets tot sind'.

\section{(d) Cultural Studies.}

That $M$. fructigena and $M$. cinerea can be distinguished by their mode of growth on sterilized culture media has already been pointed out, and further study has confirmed previous observations. Prune juice agar has hitherto proved the best substrate for distinguishing the two species when growing vegetatively. On this medium, in Petri dishes, $M$. fructigena grows out uniformly to the edge of the plate in the form of an almost regular circular disc of mycelium (Fig. 6), while $M$. cinerea produces a more irregular growth with a tendency to form lobes (Fig. 5). Another characteristic of the latter species is its habit of zonate development; when the culture has made some growth (usually when it has reached about halfway to the edge of the plate, but often before this) further development is temporarily inhibited, but is soon renewed in the form of flabelliform outgrowths of mycelium which eventually coalesce to form a definite zone (Figs. 4 and 5). In some cultures three or four distinct zones are produced in this way.

In these plate cultures of $M$. cinerea f. mali, one or more dark brown zones invariably appear, the first at $5^{-10} \mathrm{~mm}$. from the point of inoculation in about I 2 days (Fig. 4); the brown zones are less regularly produced by the Prumus form and some strains remain quite hyaline (Fig. 5). This coloration is more pronounced in tube cultures, the zones becoming more or less confluent, so that in the case of the apple form the cultures may become almost black throughout.

Sterilized potato is another useful medium for diagnosing the species, particularly when they are found within the tissues of the host as barren mycelium only. On potato both species develop fructifications, each producing conidial tufts of the colour peculiar to the species, i. e. $M$. fructigena buff yellow pustules, $M$. cinerea grey ones. The two biologic forms of $M$. cinerea grow equally well on sterilized potato, but the conidial tufts of the apple form are generally less numerous and not so well developed as those of the Prumus form, and often some difficulty is experienced in obtaining sufficient conidia for inoculation experiments. On the other hand strains 


\section{Wormald.- 'Brown Rot' Diseases of Fruit Trees. II. I65}

which have been obtained from plums and cherries have always produced conidia freely on potato.

This difference in the conidial productivity of the two forms of $M$. cinerea has been noted also in the case of cultures growing on starch jelly prepared with the 'Modified Uschinsky's Solution' as recommended by Erwin Smith (24) for bacteria. Up to the present only two strains of each form have been cultivated on this medium in comparative tests. The two plum strains produced numerous conidia, but none could. be found in the cultures of the two apple strains.

Cultural methods have also shown that there is a difference even in the mode of germination of the conidia when these are placed on prune juice agar. Typically the germ tube of $M$. fructigena grows out as a single hypha, almost straight, for some 400 to $I, 200 \mu$ before it branches to form a dendritic branching system terminal to the primary germ tube, within from 24 to 48 hours at room temperature; often a very short germ tube 10 to $30 \mu$ in length develops at the opposite end of the conidium. The germ tube of $M$. cinerea, on the other hand, usually becomes geniculate and soon produces branches at a short distance from its point of origin, so that the branch system is very irregular from the first. In both species the hyphae, after 48 hours, grow out in all directions to form a more or less circular disc of mycelium.

When growing on agar culture media both $M$. fructigena and $M$.cinerea (including the American form of Monilia) produce numerous clusters of minute 'microconidia' or 'sporidia'. These spore-like bodies are globose and about $3 \mu$ in diameter ; attempts to induce them to germinate failed.

That cultural and biochemical methods employed in the laboratory will prove of service in distinguishing between morphologically similar forms of fungi is becoming more and more evident. Such methods are indispensable to the bacteriologist, and they offer to the mycologist a wide and interesting field for study. Alsberg and Black (2) found that biochemical methods were useful in identifying species of Penicillium which are not easily distinguished morphologically, and Grossenbacher and Duggar (12) were able to distinguish parasitic and saprophytic strains of Botryosphaeria ribis by means of artificially prepared cultures.

\section{(e) American Strains of Monilia.}

Until a few years ago plant pathologists in North America had attributed Brown Rot diseases in that continent to Monilia fructigena. Recent writers, however, conclude that it is identical with Monilia cinerea, Bon.: thus Bartram (3) writes: 'The common form of brown rot of stone fruits, as found in Vermont, is due to the fungus known in Europe as Sclerotinia cinerea. This is conclusively proved not only by the measurements of the conidia, the absence of disjunctors, the grey colour of the conidial tufts, but more 
especially by the persistence of the vitality of the conidia through the winter.'

Ten strains of this American form have been received at Wye from three different localities in North America, viz. Wisconsin, Oregon, and Ontario, and from three different hosts, viz. apple, plum, and peach. They have been cultivated and examined side by side with cultures of the forms occurring in this country. It was found that the American Monilia could. be distinguished in cultures from the forms of $M$. cinerea occurring in England, in the readiness with which it produces conidia, and in its mode of growth when cultivated on prune juice agar.

The European form does not produce conidia $^{1}$ on prune juice agar or carrot agar, nor in such liquid media as fruit extracts or Coons' solution, while the American strains develop numerous well-developed pustules on all these media. On prune juice agar the American form grows out uniformly to the edge of the plate, and in this respect resembles $M$. fructigena rather than our native forms of $M$. cinerea; these cultures, however, can easily be distinguished from those of $M$. fructigena by the numerous small grey tufts of conidiophores which develop (Fig. 7).

Again, in the mode of branching of the germ tube of the conidium, on agar plates, the American form of Monilia more nearly resembles $M$. fructigena than $M$. cinerea. The germ tube shows less tendency to become geniculate than is the case with that of $M$. cinerea; it is usually at least $200 \mu$ in length before it begins to branch, and unbranched germ tubes $65^{\circ} \mu$ and $750 \mu$ in length have been observed.

\section{(f) Taxonomy.}

The results of observations and experiments recorded in the present paper show that there are two distinct species of Monilia occurring in Britain, and that they are to be distinguished as follows :

Pustules.

Dimensions of conidia.

Mode of germination of conidia on prune juice agar.

Cultures on prune juice agar plates.

Winter condition.

\section{M. fructigena.}

Buff yellow.

Average about $2 \mathrm{I} \times \mathrm{I} 3 \mu$.

Typically produces a long germ tube, 600 to $I, 200 \mu$ in length, before branching.

Growth uniform to edge of plate ; margin entire or subentire.

Pustules generally barren in winter or bearing non-viable conidia.

\section{M. cinerea.}

Grey, generally smaller than those of $M$. fructigena. Approx. average.

Winter conidia, I I. $5 \times 8 \mu$.

Summer conidia, I $7 \times$ I I $\mu$.

Germ tube branches while still quite short, often close to its point of origin ; it is usually geniculate at one or more points.

Growth zonate; margin lobed.

Pustules and conidia produced freely in winter.

1 A few conidia tufts have been observed in one instance only when prune juice agar was used, in a tube culture of a plum strain which had been growing at a fairly low temperature $\left(7^{\circ}-\mathrm{I} 5^{\circ} \mathrm{C}\right.$. $)$ for some weeks. 


\section{Wormald.- 'Brown Rot' Diseases of Fruit Trees. II. ${ }^{6} 67$}

The biological relationship of the two species to their host is also different. Observations made in Kent on affected trees, and on specimens received from other counties, show that the species occur on apples, plums, and cherries as shown in the following table. Observations on other hosts have not been sufficiently numerous for a general statement to be made of their mode of attack.

Host.

Apple trees.

Plum trees.

Cherry trees.

\section{M. fructigena.}

Produces a fruit rot and may cause cankers by invading the branches from the fruit.

Causes a fruit rot.

Causes a fruit rot.
M. cinerea.

Produces a blossom wilt and often causes cankers by invading the branches through the flowers and flowering spurs.

Produces blossom wilt, cankers, and fruit rot.

Produces blossom wilt and may kill twigs; it also causes a fruit rot.

Not only are there two distinct species of Monilia concerned in the Brown Rot diseases, but there is evidence, as presented in the preceding pages, that in Britain there are two biologic forms of $M$. cinerea, which may conveniently be referred to as forma mali and forma pruni; these may be distinguished as follows :

Monilia cinerea forma mali.

Produces a blossom wilt and canker of apple trees.

Readily secretes an enzyme which oxidizes tannins.
Monilia cinerea forma pruni.

Unable to cause a blossom wilt of apple trees.

Secretes the oxidizing enzyme far less freely.

$M$. cinerea forma mali appears to be confined to the apple; I have not yet found it on plums or cherries, although artificial inoculations have shown that it is able to infect the flowers and fruit of the plum tree.

$M$. cinerea forma pruni is the form occurring on plums, cherries, and damsons; it is found also on Pyrus japonica. The fact that it is unable to invade the flowering axis of the apple tree to cause a blossom wilt accounts for its inability to establish itself on that host.

A comparison of the morphological and cultural characters of strains of $M$. fructigena and $M$. cinerea isolated from mummied fruit sent by Dr. Quanjer from Holland showed that the two species occurring in this country are similar to those of the Continent. I have not yet been able to secure specimens of $M$. cinerea f. mali from abroad, but the description and illustrations given by Eriksson (8) of a disease of apple trees occurring in Sweden conform so closely with the appearance of the 'Blossom Wilt and Canker' disease of apple trees occurring in this country that there is good reason for assuming its occurrence on the Continent.

There is no record of the occurrence in Britain of the ascigerous stage in the life-history of either Monilia cinerea or $M$. fructigena, and all attempts at Wye to induce the development of apothecia by placing mummied fruit on the ground in the open have hitherto failed. 
The Sclerotinia stage of $M$. fructigena was first described by Aderhold and.Ruhland ( 1$)$, the genetic connexion between the ascigerous and the conidial forms being established by the development of the Monilia form from ascospores.

The same workers were also able to obtain a Selerotinia from mummied apricots, and from the ascospores obtained cultures which developed conidial pustules resembling those of $M$. cinerea; this Ascomycete they named Sclerotinia laxa, i. e. the ascigerous stage of Ehrenberg's Oidium laxum (= Monilia laxa, Sacc. et Vogl.). They considered Monilia laxa to be distinct from $M$. cinerea, morphologically with regard to the size of its conidia, and biologically from the fact that they found it occurring plentifully on apricots when neighbouring peaches and cherries were unaffected. The size of the conidia of $M$. laxa Aderhold and Ruhland give as $12.4^{-2} 3.8 \times 9.3^{-I} 5.5 \mu$, the dimensions of those of $M$. cinerea as $9.3^{-}$ $\mathrm{I} 4.5 \times 6 \cdot 2-\mathrm{I} 2.4 \mu$. It is to be observed, however, that the dimensions given for $M$. laxa conform to those of $M$. cinerea when the latter is growing in summer on plums.

To the time of writing, only one strain from apricots has been examined at Wye ; this was found on dead twigs in February I9I9. The size of the conidia was found to be from $6.5 \times 3 \mu$ to $14.5 \times 9.5 \mu$ with an average of I I $\times 7.5 \mu$ for Ioo conidia, dimensions which are of the same order as those of the winter conidia of $M$. cinerea produced on mummied plums and cherries. There seems to be no valid reason, therefore, for considering the two conidial forms $M$. cinerea and $M$. laxa as two distinct morphological species; whether the apricot has a biologic form confined to that host remains to be proved by inoculation experiments with pure cultures.

In North America a Brown Rot Sclevotinia, first discovered and described by Norton (20), is frequently found. Specimens, preserved in spirit, were sent by Norton himself to Aderhold and Ruhland, and they named it Sclerotinia cinerea, assuming it to be the ascigerous stage of the conidial form Monilia cinerea, Bon. Since, as shown in this article, the American form of Monilia is readily distinguished in cultures from the $M$. cinerea of Europe, the writer regards it as a distinct form (provisionally referring to it as Monilia cinerea forma americana) of which the Sclerotinia stage is that recently described from fresh material by Matheny (18). Whether this Sclerotinia of America will prove to be identical with, or distinct from, the ascigerous stage of the European form Monilia cinerea, Bon., must remain an open question until an Ascomycete is described the ascospores of which give rise to a Monilia morphologically and culturally identical with that occurring on Prumus spp. in Europe.

As there are reasons for suspecting that Monilia laxa and $M$. cinerea are the same morphological species, it appears probable that Sclerotinia laxa (Ehrenb.), Aderh. et Ruh., is the ascigerous stage of both the conidial forms 
Wormald.-'Brown Rot' Diseases of Fruit Trees. II. $\quad$ I69

described under those names by various authors, but until this relationship is established experimentally the present writer prefers to retain the name Monilia cinerea, Bon., for the grey Monilia occurring parasitically in Europe on the commonly cultivated species of fruit trees of the genera Pyrus and Prunus.

\section{SUMMARY.}

(I) In Britain there are two species of Monilia parasitic on fruit trees of the genera Pyrus and Prunus, viz. M. fructigena, Pers. = Sclerotinia fructigena (Pers.), Schröt., and $M$. cinerea, Bon.

(2) The two species are to be distinguished by-

(a) the colour and size of the pustules,

(b) dimensions of the conidia,

(c) mode of growth on sterilized culture media,

(d) mode of branching of germ tube of conidium,

(c) mode of parasitism.

(3) $M$. fructigena causes a fruit rot of apples, plums, and cherries, and on apple trees may produce cankers by invading the branch through the fruit.

$M$. cinerea occurs on apple, plum, and cherry trees and causes diseases as follows :

Apple trees-'Blossom Wilt and Canker' disease.

Plum trees-fruit rot, blossom wilt, cankers, and a 'Wither Tip' disease of young shoots.

Cherry trees-fruit rot, blossom wilt, and may kill twigs by entering through the flowers.

(4) In $M$. fructigena conidia production is inhibited during winter; $M$. cinerea, on the other hand, begins to develop new pustules about the beginning of December and produces conidia freely during winter and spring.

(5) The winter conidia of $M$. cinerea are considerably smaller than those produced by it in summer.

(6) The form of $M$. cinerea parasitic on apple trees is biologically and physiologically different from the form found on plum and cherry trees:

$M$. cinerea forma mali produces a blossom wilt of apple trees; it readily secretes an enzyme which oxidizes tannins.

$M$. cinerea forma pruni, when apple flowers are inoculated with conidia, attacks only the flowers actually inoculated and does not invade the axis of the inflorescence; it secretes the oxidizing enzyme far less freely than the apple form.

(7) The oxidizing enzyme is secreted freely by $M$. cinerea f. mali when growing in-

(a) liquid culture media,

(b) infected apples,

(c) infected apple spurs. 
(8) The American form of Monilia is more nearly related to $M$. cinerea than to $M$. fructigena, but in cultures it can be distinguished from the European form of $M$. cinerea by its mode of growth in cultures and by the numerous fructifications it produces on all the culture media on which it has been grown.

\section{BIBLIOGRAPHY.}

1. Aderhold, R., and Ruhland, W. : Zur Kenntnis der Obstbaum-Sklerotinien. Arb. Biol. Abt. Land- w. Forstw. Kaiserl. Gesundheitsamtes, Bd. iv, I905, pp. 427-42.

2. Alsberg, C. L., and Black, O. F.: Contribution to the Study of Maize Deterioration. U.S. Dep. Agric. Bur. Plant Ind. Bull, 27o, 1913.

3. Bartram, H. E. : A Study of the Brown Rot Fungus in Northern Vermont. Phytopath., vol. vi, I 916, pp. $7 \mathrm{I}-8$.

4. Brierley, W. B. : Experimental Studies in the Specific Value of Morphological Characters in the Fungi. Paper read at General Meeting of the Linnean Soc., London, Feb. 2I, I918.

5. Brooks, F. T. : Silver-leaf Disease. Journ. Agric. Sci., vol. iii, I913, pp. 288-308.

6. Coons, G. H. : Factors involved in the Growth and the Pycnidium Formation of Plenodomus fuscomaculans. Journ. Agric. Res., vol.v, i916, pp. 71 3-69.

7. Crocker, W., and Harrington, G. T. : Catalase and Oxidase Content of Seeds in Relation to their Dormancy, Age, Vitality, and Respiration. Journ. Agric. Res., vol. xv, No. 3, Oct. I918, pp. I37-74.

8. Eriksson, J. : Zur Kenntnis der durch Monilia-Pilze hervorgerufenen Blüten- und Zweigdürre unserer Obstbäume. Mycol. Centralbl., Bd. ii, I9I3, pp. 65-78.

9. Ewert, R.: Verschiedene Überwinterung der Monilien des Kern- und Steinobstes und ihre biologische Bedeutung. Zeitsch. f. Pflanzenkr., Bd. xxii, I9I2, pp. 65-86.

10. Fernbach, M. A. : Sur la tannase. Compt. Rend., t. I3I, I900, pp. I 2 I4-I 5 .

11. Green, J. Reynolds : The Soluble Ferments and Fermentation. Cambridge, I899.

12. Grossenbacher, J. G., and Duggar, B. M. : A Contribution to the Life-history, Parasitism, and Biology of Botryosphaeria ribis. New York Agric. Expt. Sta. Tech. Bul. I8, I9II, pp. I I $3-90$.

13. Knudson, L.: Tannic Acid Fermentation.' Journ. Biol. Chem., 1913, pp. 159-202.

14. Laborde, J. : Sur l'oxydase du Botrytis cinerea. Compt. Rend., t. ı 26, I898, pp. 536-8.

15. Lindet, L.: Sur l'oxydation du tanin de la pomme à cidre. Compt. Rend., t. 120,1895 , pp. 370-2.

16. Martinand, - : Action de l'air sur le môut de raisin et sur le vin. Compt. Rend., t. i2 i, 1895, p. 502 .

17. : Sur l'oxydation et la casse des vins. Compt. Rend., t. I24, I897, p. 5 I 2.

18. Matheny, W. A. : A Comparison of the American Brown Rot Fungus with Sclerotinia fructigena and $S$. cinerea of Europe. Bot. Gaz., vol. lvi, pp. 418-32.

19. Neger, F. W.: Beiträge zur Biologie der Erysipheen. Flora, Bd. 90, 1902, p. 237.

20. Norton, J. B. S. : Sclerotinia fructigena. Trans. Acad. Sci. St. Louis, vol. xii, 1902, pp. 9I-7.

21. Percival, J. : 'Silver Leaf' Disease. Journ. Linnean Soc., vol. xxxv, 1902, p. 395.

22. Pottevin, H. : La Tannase, Diastase dédoublant l'acide gallotannique. Compt. Rend., t. I3I, 1900, pp. I $215^{-17}$.

23. Ridgway, R.: Color Standards and Color Nomenclature. Washington, 19I2.

24. Sмith, ERwin F.: Bacteria in Relation to Plant Diseases, vol. i, p. 197 . Washington, 1905.

25. Thatcher, R. W.: Enzymes of Apples and their Relation to the Ripening Process. Journ. Agric. Res., vol. v, I9I 5, pp. 103-16. 
Wormald.- 'Browen Rot' Diseases of Fruit Trees. II. I7I.

26. Woods, A. F. : The Destruction of Chlorophyll by Oxidizing Enzymes. Cent. f. Bakt., Abt 2, Bd. v, I 899, pp. $745-54$.

27. Woronin, M.: Über Sclerotinia cinerea und Sclerotinia fructigena. Mém. Acad Imp. Sci. Saint-Pétersbourg, viii Ser., vol. x, No. 5, Phys. Math., I900, pp. I-38.

28. Wormald, H. : A Blossom Wilt and Canker of Apple Trees. Ann. Applied Biol., vol. iii, No. 4, Apr. 191 7 , pp. 159-204.

29 : A 'Wither Tip' of Plum Trees. Ann. Applied Biol., vol. v, No. I, July, 1918, pp. $28-58$.

30. $\longrightarrow$ : The 'Brown Rot' Diseases of Fruit Trees, with Special Reference to two Biologic Forms of Monilia cinerea, Bon. I. Ann. of Bot., vol. xxxiii, No. I3I, July, I919, pp. 36r-404. (Bibliography of literature on Brown Rot Diseases, pp. 398-403.)

\section{EXPLANATION OF PLATES IV AND V.}

Illustrating Mr. Wormald's paper on the 'Brown Rot' Diseases of Fruit-trees. II.

Fig. I. Plums affected by Brown Rot caused by Monilia cinerea, showing-

(a) infection arising from contagion;

(b) the small grey pustules typical of the fungus when growing on recently infected fruit.

Fig. 2. The winter condition of plums infected with $M$. cinerea; the redeveloping pustules are larger than those produced in summer.

Fig. 3. The winter condition of plums infected with $M$. fructigena; the pale pustules are smooth (non-pulverulent) and barren; the darker pustules below and on the left are covered with a brown hyphomycete.

Fig. 4. M. cinerea f. mali

Fig. 5. M. cinerea f. pruni

Fig. 6. M. fructigena

Fig. 7. American strain of Monilia

Cultures of the same age grown simultaneously under the same conditions, i.e. on prune juice agar at room temperature (about $16^{\circ}$ C.). The granular appearance in Fig. 7 is due to innumerable tufts of conidiophores with chains of conidia.

Fig. 8. The relative colour reactions with guaiacum shown by three extracts, similarly prepared, from the tissues of one and the same apple which had been artificially inoculated with two strains of M. cinerea :

A. From side infected with $M$. cinerea f. mali.

B. " " " " M. cinerea f. pruni.

C. From that portion of the apple which had not become infected. 

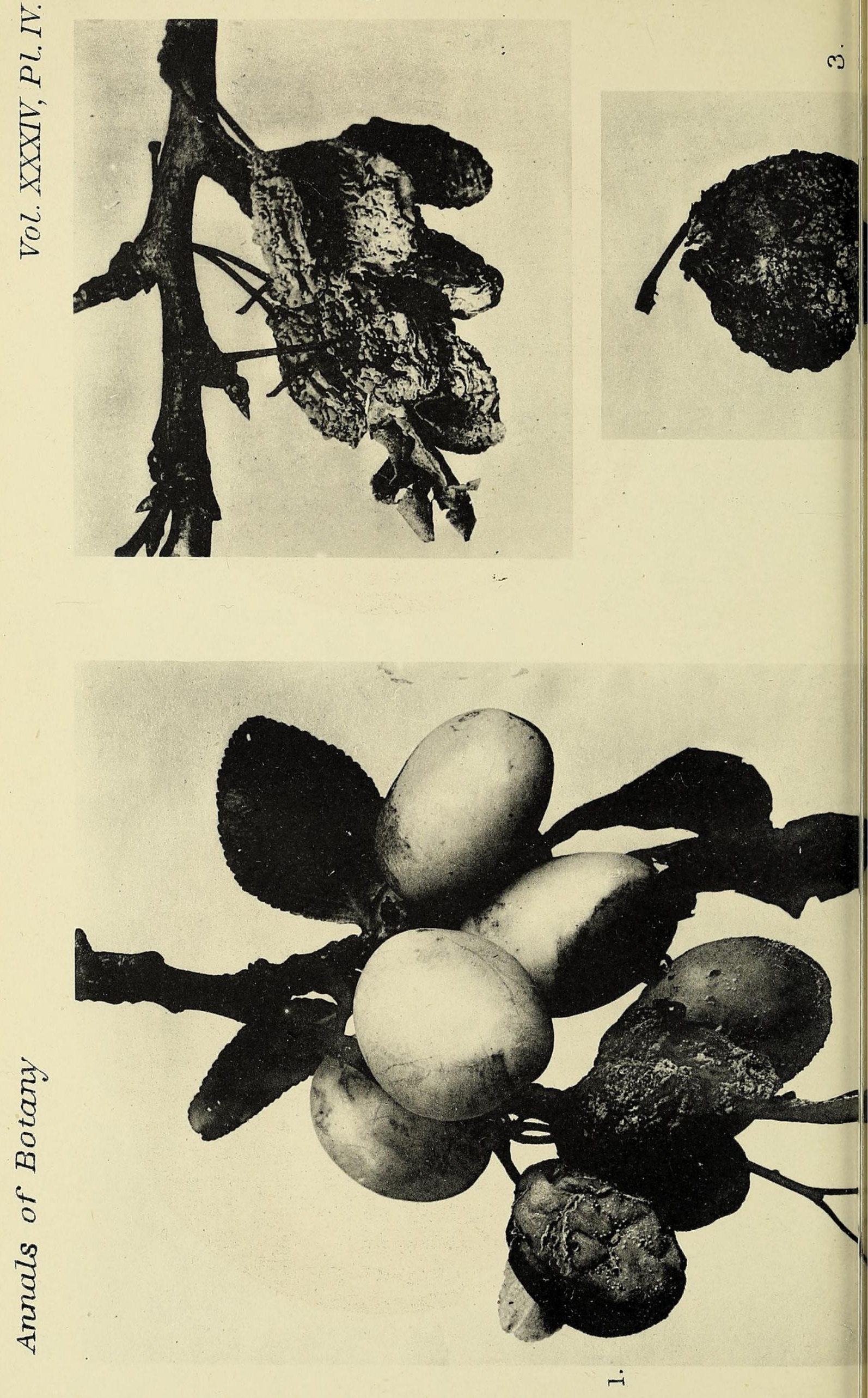


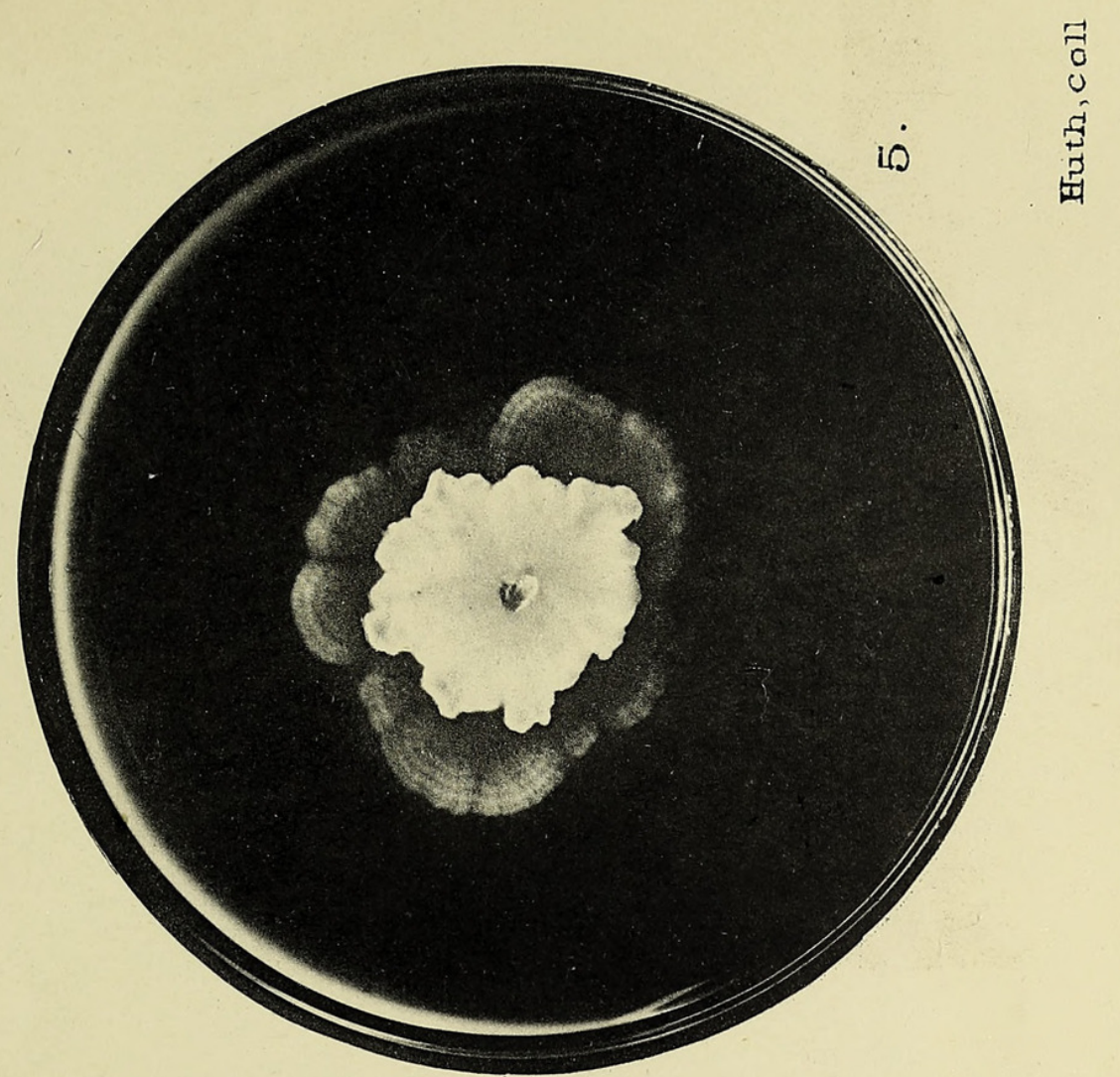

1
0
11
2
3
0
$\pi$
0

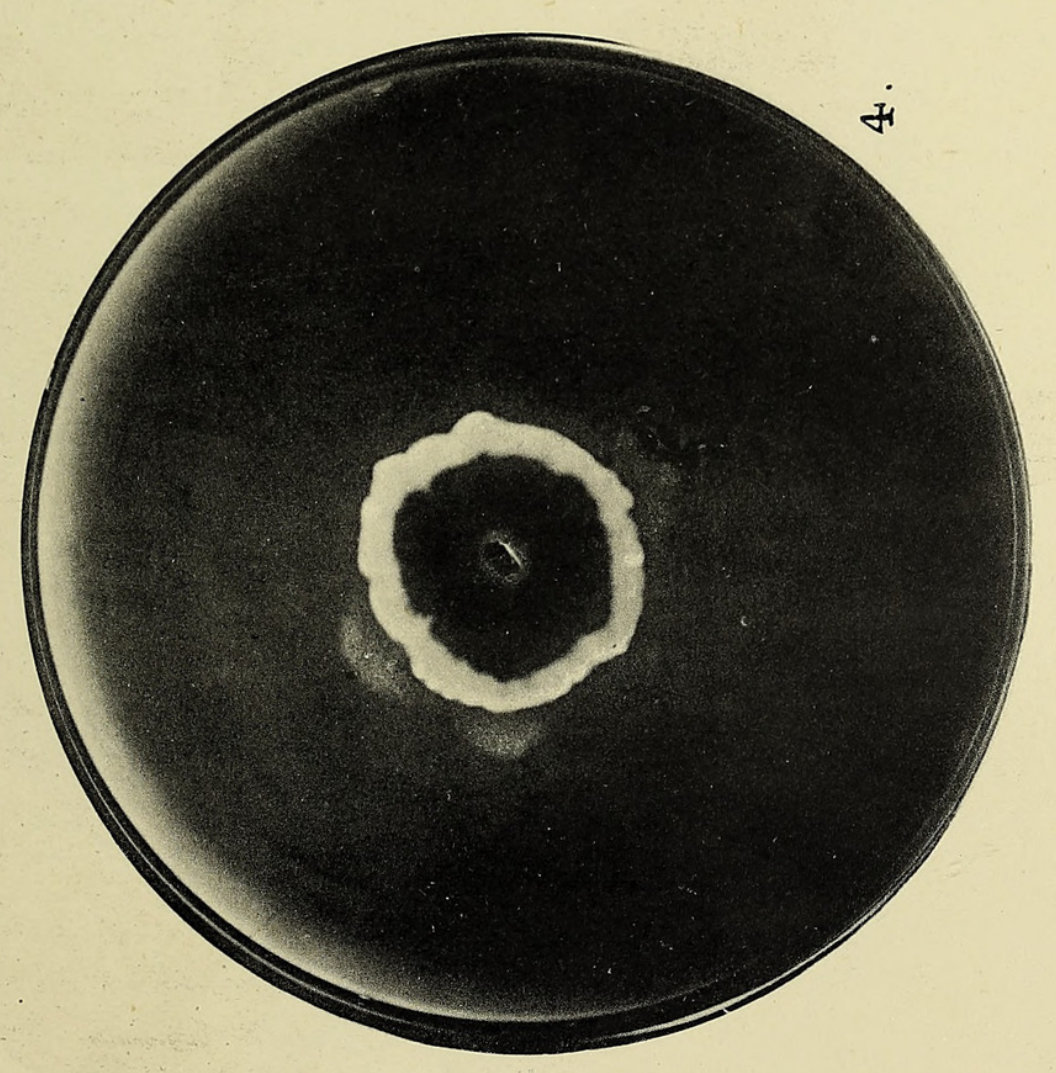

0
$\sum$
$\sum$
0
0
3 

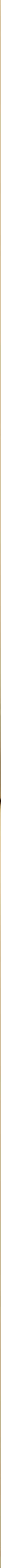

Futh, coll

WORMALD - BROWN ROT. 
Antrals of Botany.

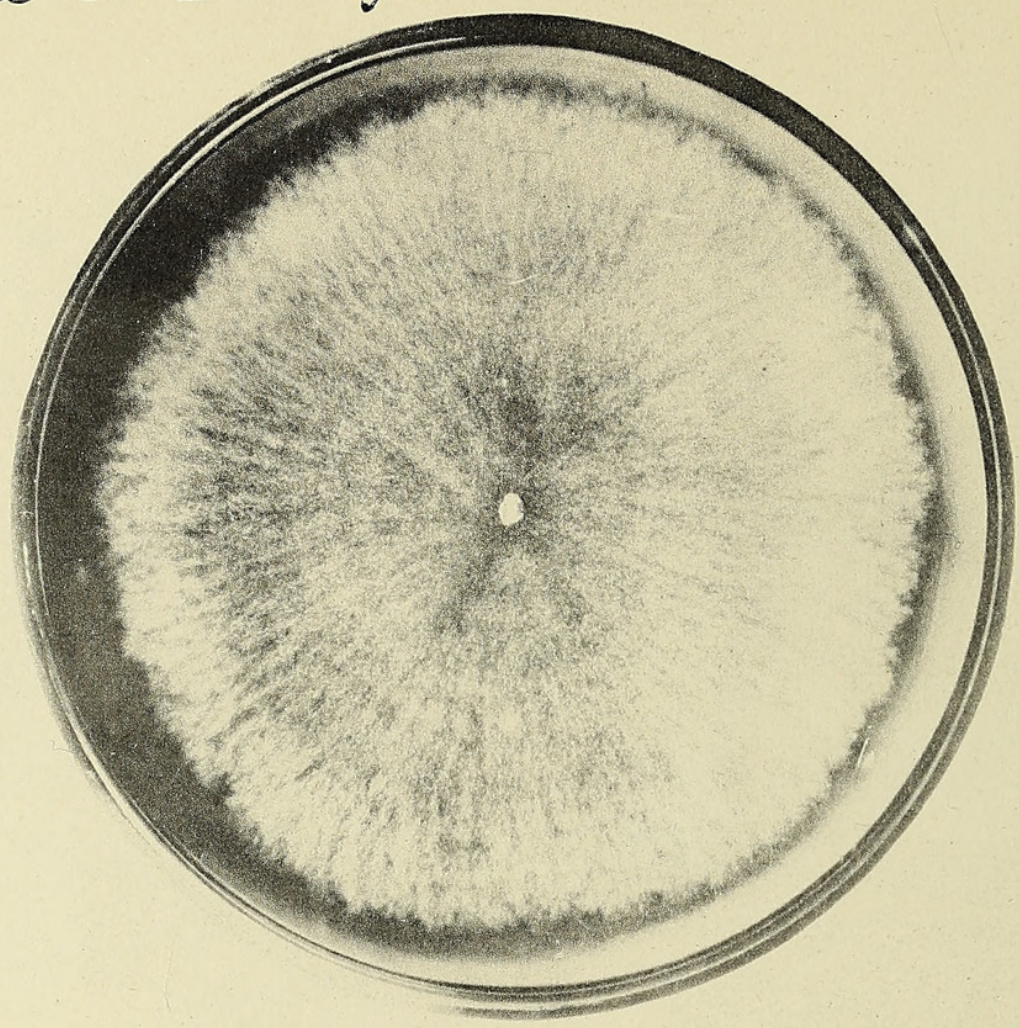

6.

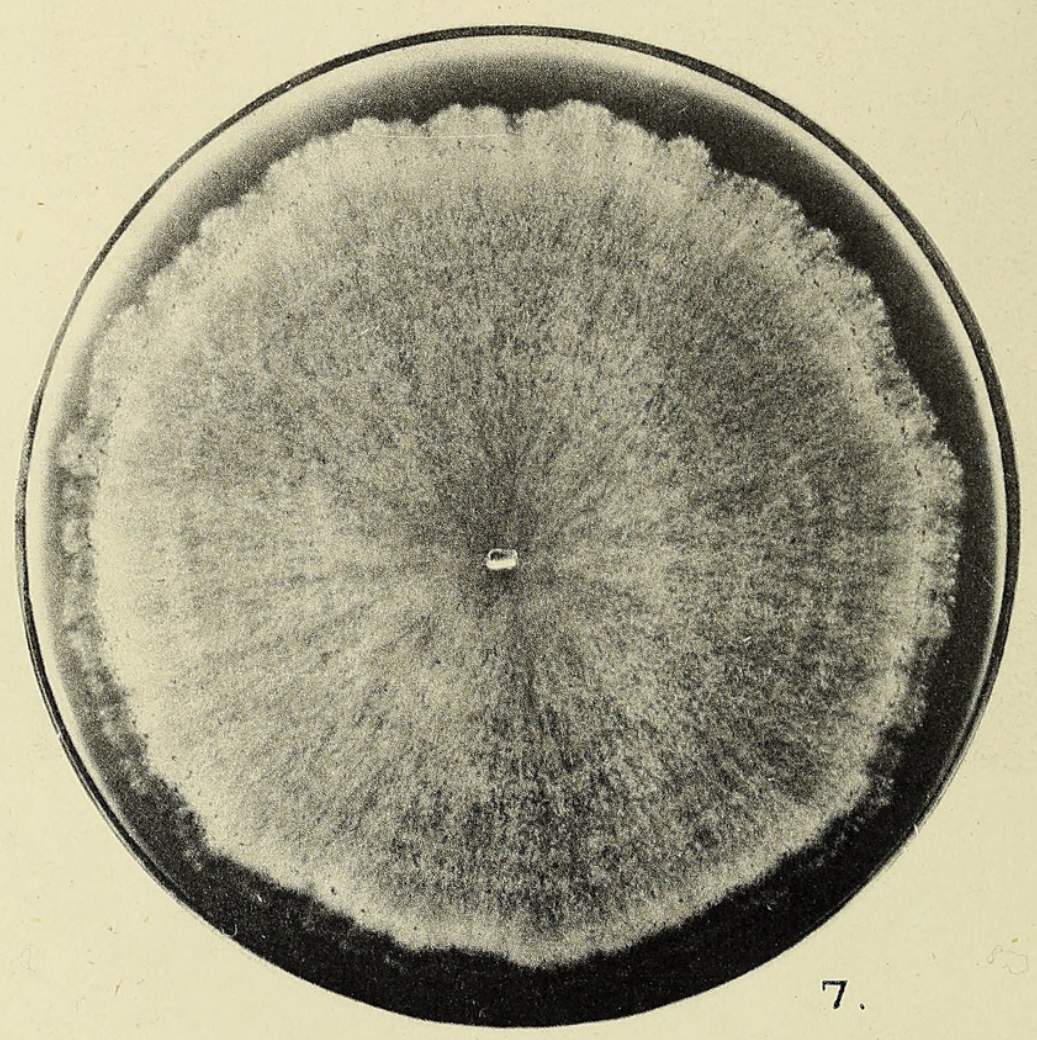

WORMALD - BAOWN ROT. 
VoL. XXXIV.PZ.V.

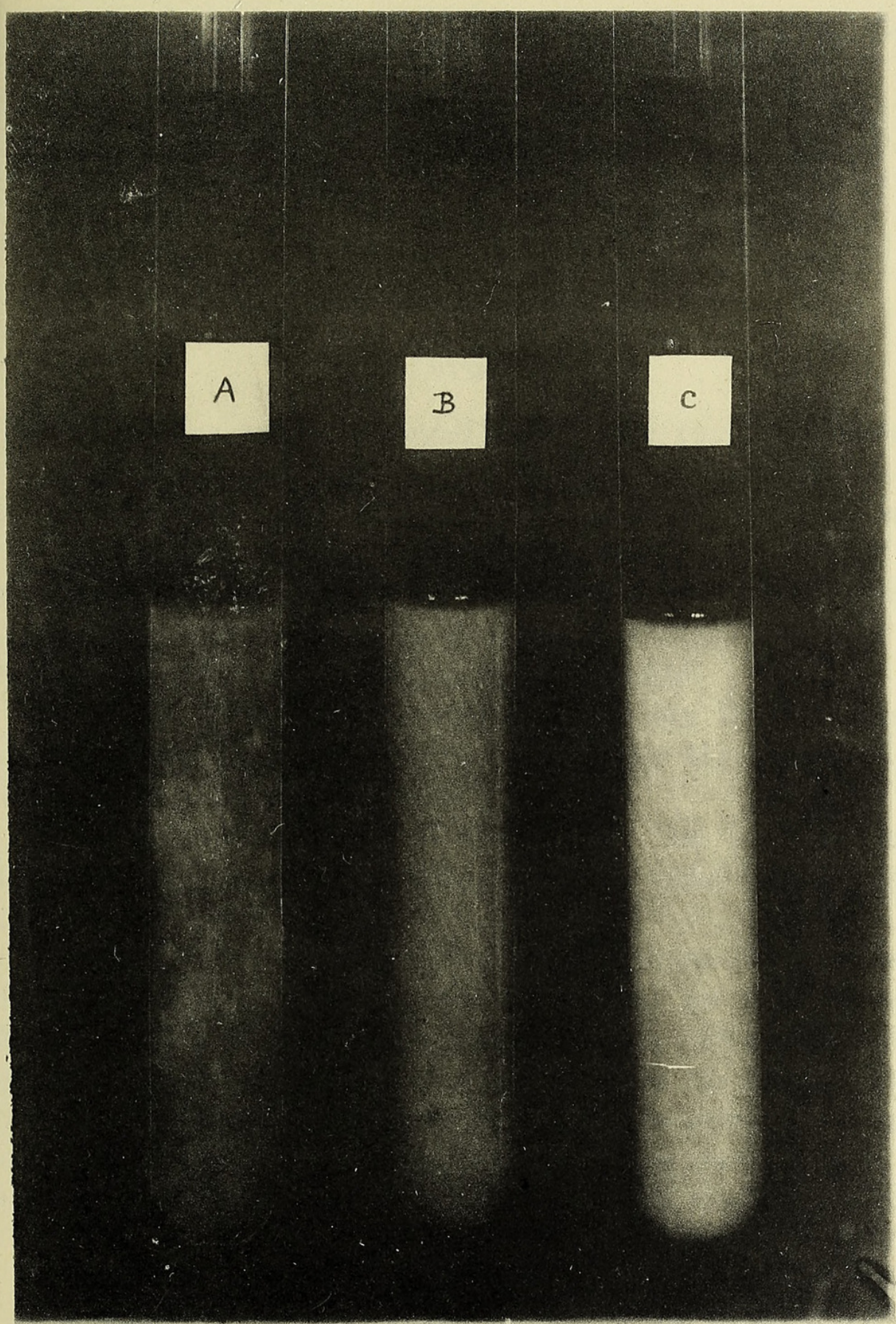

8.

Euth, coll. 


\section{$2 \mathrm{BHL}$ Biodiversity Heritage Library}

Wormald, H. 1920. "The 'brown rot' diseases of fruit trees, with special reference to two biologic forms of Monilia cinerea, Bon. II." Annals of botany 34, 143-171. https://doi.org/10.1093/aob/os-34.2.143.

View This Item Online: https://www.biodiversitylibrary.org/item/236972

DOI: https://doi.org/10.1093/aob/os-34.2.143

Permalink: https://www.biodiversitylibrary.org/partpdf/320283

\section{Holding Institution}

Smithsonian Libraries

\section{Sponsored by}

Biodiversity Heritage Library

\section{Copyright \& Reuse}

Copyright Status: Not in copyright. The BHL knows of no copyright restrictions on this item.

This document was created from content at the Biodiversity Heritage Library, the world's largest open access digital library for biodiversity literature and archives. Visit BHL at https://www.biodiversitylibrary.org. 